were grown in boxes of dung and sheltered during cold days with thin plates of Lapis specularia. Lettuce is mentioned by Charlemagne, and in the time of Albertus Magnus (1193-1280) it was grown throughout the year. From the Norman invasion of England until the middle of the sixteenth century, gardening appears to have been very greatly subordinated by the political unrest. Its development in the serenteenth century was closely bound with the herbalists Gerard and Parkinson. The initiation of French gardening, involving the protection of early plants with glass cloches, appears to have been due to Jean de la Quintinye in the second half of the seventeenth century, and crops were then brought to maturity upon hotbeds. Joln Evelyn, John Woolridge and Prof. Bradley added their quota of horticultural development in the succeeding hundred years, to be followed by J. C. Loudon. French gardening declined in the later half of the nineteenth century, however, only to give place to the more workable and convenient methods of glasshouse culturo which provide our present supplies of extra-seasonal vegetables.

\section{A New Cyclotron}

THE cyclotron constructed in the workshop of the Physics Department of Purduo University, Indiana, is described in the November issue of the Journal of the Franklin Institute by the five members of the staff who designed it. So far as possible standard materials available in industry have been used in its construction. The magnet is of low carbon steel $3 \mathrm{~m}$. long and $2 \mathrm{~m}$. high, and the pole pieces of special shape $1 \mathrm{~m}$. diameter. The magnetizing coils are of thin copper tube through which cold water circulates. Each coil is square in section with side $30 \mathrm{~cm}$. The oscillator is of the tuned grid tuned plate type, of frequency $10.9 \mathrm{MIc}$., with neutralizing condensers. It takes 3 amperes at 8,500 volts. The chamber is of the Berkeley type with floor and top of steel plate $3 \mathrm{~cm}$. thick with special arrangements for controlling the bending due to external pressure, which has been found to increase the beam intensity. The ions are supplied by an arc near the centre of the cyclotron. The instrument yields 16.5 million volts for $\mathrm{He}^{+}+$ ions.

\section{The National Institute for Research in Dairying}

The annual report of the National Institute for Research in Dairying, Reading, covering the year ending September 30, 1938, has just been published; this seems an unnecessarily long delay. Develop. ments, administrative matters and changes in the staff are outlined, and a summary is given of the research work that has been carried out in the various departments. Among tho last named is an investigation in the Department of Physiology and Biochemistry on the nutritive value of sprayr-dried milk, roller-dried milk and evaporated milk. The biological values of the proteins, and the content of vitamin $A$ and of vitamin $C$ are much the same for all three products, but vitamin $B$ is much reduced in the evaporated milk--to half that present in the other two. The results show that properly dried milk retains to a remarkable extent the nutritive value of the raw product and that modern methods of spray drying yield a powder of high nutritional quality. An appeal is made for donations to meet the cost of new buildings which are urgently needed to reliove the acute congestion in the existing laboratories.

\section{International Society of Medical Hydrology}

A MEETIsG of the general purposes committee of the International Society of Medical Hydrology was held in London on November 17 last to deal with emergency measures made necessary by the War, and also by the death of the Society's chairman of council, Dr. E. P. Poulton. Dr. J. Barnes Burt was elected interim chairman of council, and four addi. tional vice-chairmen, all in countries 'neutral' in the present conflict, were appointed. It was further resolved that the cash balance remaining should be set aside for reconstruction of the Society after the War, and the general secretary was given indefinite leave of absence without pay and instructed to close the London office. The Society's address will be, until further notice, that of the honorary treasurer, Dr. G. D. Kersley, 6 The Circus, Bath.

\section{Medical Organizations of India}

Tue medical organizations of all-India are reviewed by Major-General Bradfield, director-general of the Indian Medical Service, in a volume of 658 pages entitled "An Indian Medical Review" (Government of India Press, New Delhi, 1938). Administrative organization and the medical profession and services, hospitals and nursing, maternity service and pharmacy, and medical education and research, aro all surveyed in the first 280 pages, the remainder of the book containing full statistics of hospitals, dispensaries and other medical institutions. This volume should prove a useful supplement to the "Annual Report of the Public Health Commissioner with the Government of India".

\section{The Night Sky in January}

Durisg this month, the night shortens in the latitude of London by 1 hour 10 minutes, reckoning from sunset to sunrise. The moon is new on January 9, and full on January 24. Occultations of stars by the moon include three stars of magnitude $3-4$ of the Hyades cluster which precedes Aldebaran. The disappearances as seen from Greenwich take place on January 20 as follows: $\delta$ Tauri at $21 \mathrm{~h} .37 \cdot 9 \mathrm{~m}$. at position angle $107^{\circ}$ from the north point of the moon's disk: 64 Tauri at $22 \mathrm{~h} .31 \cdot \mathrm{lm}$. at $142^{\circ}$ and 68 Tauri at $23 \mathrm{~h} .29 \cdot 0 \mathrm{~m}$. at $16^{\circ}$. On January 23 , $\lambda$ Geninorum $(3.6 \mathrm{~m}$.) is occulted at $20 \mathrm{~h} .20 .9 \mathrm{~m}$. at $121^{\circ}$. There is a fine array of planets in the evening sky-Venus, Mars, Jupiter and Saturn-whilst Uranus, a faint 6th magnitude object, is in Aries near the 6th magnitude star 53 Arietis. At the beginning of the month, MIars is overtaking Jupiter in the eastward shift of the two planets among the stars by about $\frac{1}{2}^{\circ}$ a day, and on January 7 at $15 \mathrm{~h}$. there is a conjunction, the geocentric distance between 